
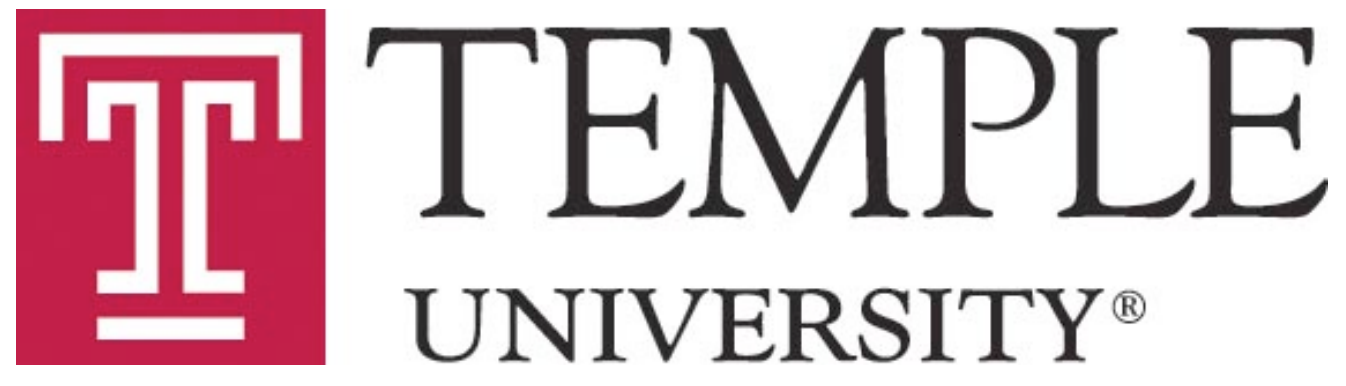

\title{
Substance Use Treatment Provider Behavior and Healthcare Reform: Evidence from Massachusetts
}

\author{
Johanna Catherine Maclean \\ Department of Economics \\ Temple University
}

Brendan Saloner

Department of Health Policy and Management

Johns Hopkins University

Department of Economics

DETU Working Paper 15-11

September 2015

1301 Cecil B. Moore Avenue, Philadelphia, PA 19122

http://www.cla.temple.edu/economics/faculty/detu-working-paper-series/ 


\title{
SUBSTANCE USE TREATMENT PROVIDER BEHAVIOR AND HEALTHCARE REFORM: EVIDENCE FROM MASSACHUSETTS
}

\author{
Johanna Catherine Maclean ${ }^{\mathrm{a}^{*}}$ \\ Brendan Saloner ${ }^{\mathrm{b}}$ \\ July, 2015
}

\begin{abstract}
Major expansions of health insurance coverage provide new revenue opportunities for safety-net providers, but may also create new capacity pressures for these providers. We examine the impact of the 2006 Massachusetts healthcare reform on substance use disorder (SUD) treatment - a type of safety net healthcare - providers' behaviors using a differences-in-differences design. We test whether the reform influenced admissions, daily censuses (the number of clients in treatment on a given day), services offered, and accepted forms of payment. Our findings suggest that Massachusetts providers altered their care practices following the reform. Admissions increased by $17.1 \%$ and daily censuses increased by $4.7 \%$. The number of services offered increased by $3.5 \%$, programs for special populations decreased by $24.1 \%$, and use of pharmacotherapies increased by $11.3 \%$. Massachusetts providers increased acceptance of private insurance increased by $2.7 \%$. We find that such providers were less likely to accept self-pay $(1.7 \%)$ and provide uncompensated care (1.4\%). Responsiveness was generally greater for forprofit than nonprofit providers. These findings suggest that, following major healthcare reform, Massachusetts SUD treatment providers absorbed a larger number of individuals seeking treatment, but effects on quality of care were somewhat mixed and individuals without insurance may have experienced difficulty in accessing care.
\end{abstract}

Keywords: healthcare; safety net; provider behavior; substance use disorders; healthcare reform.

JEL classification: I1; I11; I18

${ }^{a}$ Associate Professor, Department of Economics, Temple University, 1301 Cecil B. Moore Avenue, Ritter Annex 869 (004-04), Philadelphia, PA 19122, Telephone: 215-204-0560; E-mail: catherine.maclean@temple.edu.

${ }^{\mathrm{b}}$ Assistant Professor, Department of Health Policy and Management, Bloomberg School of Public Health, Johns Hopkins University, 624 N. Broadway, Hampton House 344, Baltimore, Maryland 21205, Telephone: 410-502-2116, Email: bsaloner@jhu.edu.

${ }^{\dagger}$ Authors listed in alphabetical order. * Corresponding author.

Acknowledgements: We thank seminar participants at the University of New Mexico Economics Seminar Series and the International Health Economics Association World Congress 2015, and Doug Webber for helpful comments. We are grateful to Paige Gianfortune for editorial assistance. All errors are our own. 


\section{INTRODUCTION}

Beginning in late 2013, the number of uninsured Americans began to decline with implementation of the core coverage provisions of the Patient Protection and Affordable Care Act (ACA). The ACA represents a historic transformation of the American healthcare system. Key components of the Act are new federal funds to allow states to expand Medicaid to low income adults, subsidized private insurance plans sold through online health insurance exchanges, standardization of covered benefits in private health insurance plans, and mandates to purchase insurance for individuals and some employers. The available estimates suggest that between 2013 and 2016 the uninsured rate in the U.S. will decline from $20 \%$ to $11 \%$ (Congressional Budget Office, 2013). Thus, while the ACA is predicted to substantially reduce un-insurance, over one in ten individuals will remain uninsured for some time.

Although this reform has potential to increase coverage, expand and strengthen the healthcare system, and improve public health, there is concern among policymakers that healthcare providers are not prepared to absorb increases in demand (Anderson, 2014). Of particular concern are safety net healthcare providers (Buck, 2011, Katz, 2010, Redlener and Grant, 2009), who often operate with precarious finances (Institute of Medicine, 2000). Safety net providers 'deliver a significant level of healthcare to uninsured, Medicaid, and other vulnerable populations' (Institute of Medicine, 2000). Such providers are important as they meet the healthcare needs of the most vulnerable members of society: the poor and the uninsured.

Safety net healthcare in the U.S. is characterized by limited capacity relative to demand, constrained resources, and inadequate use of basic administrative technologies such as electronic billing systems (Levit et al., 2013, Buck, 2011, Capoccia et al., 2012, Carr et al., 2008, McLellan 
et al., 2003, Stein et al., 2015, Tang et al., 2003, Shields et al., 2007, Katz, 2010). These vulnerabilities raise questions regarding the ability of safety net providers to adapt to the ACA.

To gain insights to how the safety net responds to major healthcare reforms such as the ACA, we look to a recent, analogous experience: the 2006 Massachusetts healthcare reform. This ambitious state-level reform is considered the blueprint for the ACA (Gruber, 2011). We focus on substance use disorder (SUD) treatment providers. Because SUD providers treat a disproportionate share of vulnerable populations (Levit et al., 2013), SUD treatment is an example of safety net healthcare and therefore observing the response of such providers may yield insights on safety net care generally in the post-ACA era.

SUDs impose substantial costs on society as they are linked with healthcare use (Balsa et al., 2009), morbidity and mortality (Carpenter and Dobkin, 2009), crime (Carpenter, 2007), social service use (Jayakody et al., 2000), and traffic accidents (Adams et al., 2012). Importantly, specialty treatment has been shown to reduce SUDs and their associated harms (Stewart et al., 2002, Lu and McGuire, 2002, Swensen, 2015). Understanding how SUD providers respond to large scale healthcare reform is important for promoting public health and minimizing social costs. SUDs are disproportionately high among uninsured populations likely to gain access to insurance through the ACA (Busch et al., 2013). Therefore, the ACA has the potential to provide SUD treatment to a population with elevated need for such treatment.

We use detailed data on the near universe of U.S. specialty SUD treatment providers between 2004 and 2012 coupled with a differences-in-differences strategy. We examine several margins along which specialty SUD treatment providers may respond to healthcare reform: number of admissions, daily censuses, services, and accepted forms of payments. We consider heterogeneity by ownership structure (for-profits vs. non-profits). 


\section{Massachusetts healthcare reform and SUD treatment}

\section{II.A Background}

In 2006, Massachusetts embarked on an ambitious statewide reform aimed at achieving near universal health insurance coverage. This reform has been extensively examined by economists. We refer readers to an excellent review by Gruber (2008) and briefly summarize reform components most relevant to our study here.

Key elements included subsidies to expand private insurance sold through an online marketplace, increased public insurance eligibility, health insurance market reforms, individual and large employer coverage mandates, and a reduction in the financial support for safety net care (i.e., uncompensated care pool and supplemental funds to safety net hospitals).

To satisfy the coverage mandates, individuals are required to purchase health insurance plans that included regulated benefits, including SUD treatment (The Massachusetts Health Insurance Connector Authority, 2008). The Massachusetts Medicaid program provided relatively generous coverage for SUD treatment during the reform period: no cost-sharing, priorauthorization, or service limitations (Kaiser Family Foundation, 2015). Thus, the reform ensured that all individuals enrolling in eligible insurance plans received coverage for SUD treatment.

\section{II.B Mechanisms through which the reform may influence SUD treatment}

There are several mechanisms through which the Massachusetts healthcare reform may have influenced the provision of SUD treatment, in terms of both treatment quantity and quality.

First, the reform increased the share of consumers in Massachusetts with insurance that covered SUD treatment. Overall, we expect that SUD treatment providers will admit more patients who gained access to SUD benefits through the reform, but that (at least some) would curtail provision of care to the least profitable patients: those that receive free or discounted care. 
The impacts of the reform could extend beyond the quantity of treatment supplied. Pauly and Pagan (2007) document that the share of uninsured patients in market can alter the quality of healthcare services offered if the uninsured value different types of healthcare services than insured patients. We expect that following the reform aggregate demand for services will shift toward the preferences of the newly insured. However, the reform increased both private insurance and public (Medicaid) coverage, and patients holding these two types of coverage may demand, or be eligibility through their respective plans for, different types of services.

Several factors may mute Massachusetts providers' response. SUD providers have historically had low use of insurance (public or private) and may not have the administrative capabilities (e.g., billing software) to receive payments or to meet reporting requirements of insurers (Buck, 2011). Lack of infrastructure may prevent, or at least delay, the ability of providers to respond. At the same time, SUD providers are often operating close to treatment capacity (Carr et al., 2008, Andrews et al., 2013) and may lack the physical space to increase admissions. Moreover, such providers may have limited capital to finance large-scale capacity increases (Institute of Medicine, 2000). Adding to SUD providers' financial pressures, the reform reduced uncompensated care payments available to safety net providers (Gruber, 2011).

For providers to expand treatment they must experience increases in demand. For several reasons, such demand increases may not occur. First, there is stigma surrounding SUD treatment, which may mute demand. Second, the newly insured may opt to receive treatment in non-specialty settings (e.g., physician's offices). Third, there is evidence from previous expansions that the newly insured have difficulty navigating the SUD treatment system, and such difficulty impedes their ability to translate insurance into treatment (Saloner and Cook, 2014). 
Whether, and to what extent, SUD treatment providers respond to increased demand for treatment services could depend on their ownership status. Research suggests potential differences in expenditures, offered services, and quality by ownership status (Silverman and Skinner, 2004, Sloan et al., 2001, Horwitz, 2005, Lakdawalla and Philipson, 2006, Bachhuber et al., 2014, Olmstead and Sindelar, 2005). We expect for-profit providers to be more likely to respond to incentive changes to minimize costs and maximize revenues.

\section{Reform impacts}

An extensive literature has explored the impact of Massachusetts' reform on outcomes related to access to care, utilization, and health. In general, studies have found that the reform increased coverage (Long et al., 2009, Long, 2008), increased access to a usual source of care (Long and Masi, 2009), increased use of preventive and ambulatory healthcare (Kolstad and Kowalski, 2012, Miller, 2012b), decreased use of avoidable care (Miller, 2012a, Kolstad and Kowalski, 2012), and improved health (Courtemanche and Zapata, 2014, Sommers et al., 2015). Of particular relevance, several medical studies suggest that, following the reform, both insured and uninsured individuals continued to use safety net providers as a usual source of care (McCormick et al., 2012, Nardin et al., 2012, Ku et al., 2011, Mohan et al., 2013).

To our knowledge, only one prior study has examined the response of SUD treatment providers in Massachusetts following healthcare reform. Capoccia et al. (2012) interviewed staff at five non-profit SUD providers after the reform. Admissions were relatively flat post-reform, and some services that had been previously supported by public payers decreased. Most providers experienced increases in revenue but did not receive an influx of new patients. Providers were able to expand service offerings to some extent, but copayment requirements 
constrained providers since unpaid copayments were absorbed as a loss by providers.

Administrative burdens from insurers were cited as obstacles to expansions.

These findings suggest that the expansion of insurance coverage induced by the reform may not have straightforwardly translated to increased utilization or expansion of offered services. However, the studied providers are not necessarily representative of the providers in the state and without a comparison group it is difficult to disentangle trends in Massachusetts from other contemporaneous trends.

A recent paper by Maclean et al. (2015) is mostly closely related to our study in that it examines supply-side responses to insurance reform - state mandates for coverage of SUD treatment in private insurance plans. Findings suggest that, in response to insurance mandates, providers increase (decrease) acceptance of private (public) insurance, and reduce the provision of free or discounted care. The bundle of offered services is unchanged. Although this paper is important, it focuses exclusively on private insurance expansions and cannot provide evidence on the impacts of large-scale health reform, such as the Massachusetts reform and ACA, which simultaneously increase private and public coverage among a large share of the population.

\section{DATA, VARIABLES, AND METHODS}

\section{IV.A National Survey of Substance Abuse Treatment Services}

Our primary data source is the National Survey of Substance Abuse Treatment Services (N-SSATS). These data provide detailed provider-level information on nearly all providers that offered specialty SUD treatment between 1997 and 2012. We focus on the years 2004-2012. SAMHSA defines a specialty SUD treatment facility as a hospital, a residential SUD facility, an outpatient SUD treatment facility, or other facility with an SUD treatment program that offers: 1) 
outpatient, inpatient, or residential/rehabilitation SUD treatment; 2) detoxification treatment; 3) opioid treatment; or 4) halfway-house services that include SUD treatment.

The N-SSATS data provide a 'snapshot' of one day, March $1^{\text {st }}$, of a facility's operations. N-SSATS administrators send a survey to all known specialty providers each year. A staff member completes the survey. Over our study period the N-SSATS response rates were over $91 \%$ in each year. The N-SSATS is an unbalanced panel of providers and we have 101,713 provider/year observations in our analysis dataset. We consider multiple outcomes and, for this reason, our sample sizes vary across outcomes.

\section{IV.B Outcome variables}

We consider a range of margins along which SUD providers may respond to the Massachusetts health reform. We consider the annual number of admissions, the total number of clients in the facility on the census day (daily census), and the number of clients across two treatment modalities: inpatient (hospital and residential) and outpatient. Considering the number of clients receiving treatment in these two settings allows us to study (albeit imperfectly) how treatment intensity may have changed following the reform. Inpatient treatment is more intensive than outpatient treatment, and individuals without insurance that covers SUD treatment may have difficulty accessing more intensive treatment forms. These categories are not mutually exclusive, $12 \%$ of providers provide care in both settings. We take the logarithm to address skewness, coefficients have the interpretation of an approximation to the percent change.

To assess the degree to which providers may alter the bundle of services they offer following healthcare reform, we consider the number of testing (e.g. HIV testing) and ancillary services (e.g., transportation assistance), ${ }^{1}$ and programs for special populations (e.g., seniors). ${ }^{2}$

\footnotetext{
${ }^{1}$ Comprehensive SUD assessment at intake, comprehensive mental health assessment at intake, alcohol blood test,
} illicit drug/alcohol urine test, hepatitis B testing, hepatitis C testing, HIV testing, other STD testing, TB testing, 
We also consider an indicator for the use of any pharmacotherapies (e.g., methadone). ${ }^{3}$ These attributes are viewed by national addition experts as critical components of effective SUD treatment (National Institute on Drug Abuse, 2012). ${ }^{4}$

We examine forms of accepted payment: private health insurance, Medicaid, other public health insurance (Medicare, state-financed insurance, Federal military), and self-payment and other payment forms ('self-pay'). We also consider the provision of discounted care: acceptance of a sliding-fee-scale, other forms of pay assistance, and provision of uncompensated care. Provision of services for those with limited or no means to pay for care reflects care for vulnerable populations.

We consider heterogeneity in provider response based on ownership status: non-profit providers (government or private non-profit) and private for-profit providers.

\section{IV.C State-level variables}

SUD treatment provider behaviors are plausibly influenced by myriad factors, independent of healthcare reform. We attempt to control for a detailed set of state-level variables that proxy such factors. To this end, we merge state-level demographic variables (sex, age, race/ethnicity, education, family income) from the Annual Social and Economic (ASEC) Supplement to the Current Population Survey (CPS) into the N-SSATS on state and year. Economic conditions may influence insurance coverage and need for SUD treatment (Cawley et al., 2013, Davalos et al., 2012). We proxy economic conditions with the seasonally adjusted

discharge planning, aftercare counselling, case management, childcare, social service assistance, employment assistance, housing assistance, domestic violence education, HIV/AIDS education, transportation assistance, acupuncture, residential beds provided for children, individual counselling, group counselling, family counselling, outcome follow up after discharge, and non-English treatment provided.

${ }^{2}$ Certified opioid treatment program, DUI, adolescents, dually-diagnosed, criminal justice, HIV/AIDS, gays/lesbians, seniors, women, pregnant/postpartum women, men, and other programs.

${ }^{3}$ Antabuse, naltrexone, and methadone .

${ }^{4}$ The N-SSATS has undergone several major re-designs since its inception in 1997. These re-designs affect which variables are available in each year. In selecting the special programs and testing services to include, we chose those services that were reported in each year of the N-SSATS between 2004 and 2012. 
annual state unemployment rate from the Bureau of Labor Statistics Local Area Unemployment Statistics database. We control for state population using data from the U.S. Census.

\section{IV.D Methods}

We use a differences-in-differences (DD) design to study the impact of the reform the provision of SUD treatment outlined in Equation (1):

(1) $Y_{i s t}=\alpha_{0}+\alpha_{1} D D_{s t}+\alpha_{2}^{\prime} X_{s t}+\theta_{s}+\tau_{t}+\varepsilon_{i s t}$

Where $Y_{i s t}$ is an outcome for facility $i$ in state $s$ in time $t$. $D D_{s t}$ is the interaction between the treatment group (Massachusetts) and an indicator for the post-reform era (2007-2012), and thus captures the average change in outcomes in Massachusetts relative to our comparison group (described later) before and after the reform. Because the N-SSATS survey date is March $1^{\text {st }}$ and reform was implemented beginning in April 2006, our pre-treatment period is 2004-2006 and our post-treatment period is $2007-2012 .{ }^{5} X_{s t}$ is a vector of time-varying state-level characteristics. $\theta_{s}$ and $\tau_{t}$ are vectors of state and year fixed effects. $\varepsilon_{i s t}$ is the error term.

A necessary assumption for the DD model to uncover estimates of the causal effect of Massachusetts healthcare reform on SUD provider behavior is that the treatment and comparison group would have trended similarly in terms of the outcome variables in the absence of healthcare reform. Thus, it is vital to identify a comparison group for which this assumption is likely to hold. We follow Courtemanche and Zapata (2014) and use all states with the exception of California, Maine, Oregon, and Vermont. We choose to exclude these states as they enacted major healthcare reforms either during or slightly before our study period, and were to some extent treated. ${ }^{6}$ Although the parallel trends assumption is necessary for the DD model to

\footnotetext{
${ }_{6}^{5}$ Results are robust to treating 2006 as a treatment year and to excluding the policy change year (2007).

${ }^{6}$ Courtemanche and Zaparta chose to exclude Hawaii due to data limitations. We retain this state in our comparison group, but our results are robust to excluding it. Maine implemented healthcare reform in 2003, all other states implemented reform during our study period California (2007), Oregon (2007), and Vermont $(2005,2011)$.
} 
estimate causal effects, it is untestable as it requires observing the treatment group in the untreated state in the post-treatment period. Instead we provide suggestive evidence on this assumption.

We cluster our standard errors around the state. Clustering at this level may lead us to under-estimate standard errors. We therefore follow Courtemanche and Zapata (2014) and consider estimates generated using the clustered standard errors to be statistically significant if they are distinguishable from zero at the $5 \%$ level or better (as opposed to the standard $10 \%$ threshold). We estimate an additional regression model to understand the dynamics between the reform and SUD provider behavior. We divide the post-treatment period into an 'early' period (2007-2009) and a 'late' period (2010-2012).

\section{SECTION IV. RESULTS}

\section{IV.A Summary statistics}

Table 1 reports summary statistics for Massachusetts and comparison states in the pretreatment period (2004-2006). Providers in Massachusetts had higher annual admissions and total daily censuses than the comparison states: 489 vs. 303 and 124 vs. 88 . Inpatient daily censuses were roughly the same in the two groups (27) while outpatient daily censuses were higher in Massachusetts (157 vs. 87). Massachusetts providers offered more services and programs relative to providers in comparison states, and Massachusetts providers were more likely to use pharmacotherapies. Providers in comparison states were more likely to accept private insurance and self-pay, and more likely to accept Medicaid and other non-Medicaid public insurance. Provision of discounted care was more common in Massachusetts providers. In terms of demographics, Massachusetts was more advantaged.

\section{IV.B Research design validity}


To help establish that the comparison states provide a credible counterfactual for Massachusetts we examine trends in our outcome variables in the pre-reform period for our treatment and comparison group.

First, we report graphical, unadjusted trends between 2004 and 2006 in Massachusetts and comparison states. Second, we estimate regressions outlined in Equation (2) in this period: (2) $Y_{i s t}=\beta_{0}+\beta_{1}$ Time $_{t}+\beta_{2}$ Treat $_{s t} *$ Time $_{t}+\beta_{3}^{\prime} X_{s t}+\theta_{s}+\tau_{t}+\mu_{i s t}$ Where $Y_{i s t}$ is one of our outcomes, Time $_{t}$ is a linear time trend, and Treat $t_{s t} *$ Time $_{t}$ is the interaction between an indicator for Massachusetts and the linear time trend. All other variables are as defined earlier, the $\beta$ 's are the parameters to estimate, and $\mu_{i s t}$ is the error term. We estimate the model with least squares for continuous outcomes and a linear probability model for binary outcomes. Standard errors are clustered around the state. The interaction term allows us to test whether our treatment and comparison groups were trending similarly in the pre-reform period (parallel trends test). If we cannot reject the null of parallel trends between the treatment and comparison groups in the pre-reform period, this finding can provide suggestive evidence that we have selected a suitable comparison group.

Figures A1, A2, and A3 plot mean values for admissions and daily censuses; services, programs, and pharmacotherapies; and accepted forms of payments respectively. The data are aggregated to the treatment/year level and weighted by the number of providers in a state year. The trend analyses suggest that the treatment and comparison groups followed broadly similar patterns in the pre-treatment period. We next examine adjusted differences in trends using Equation (2). Results are reported in Tables 2A (admissions, daily censuses), 2B (services, programs, pharmacotherapies), and 2C (accepted forms of payments). We cannot reject the null 
of no difference in trends in the pre-treatment period at the $1 \%$ level in all but one regression: acceptance of self-pay. Thus, readers should interpret the self-pay results with some caution.

\section{IV.C Admissions and daily censuses}

Table 3 reports regression results for admissions and daily censuses outcomes. In the basic DD model, Model 1, we find that the reform led to a $17.1 \%$ increase in annual admissions, and a $4.7 \%, 7.9 \%$, and $13.7 \%$ increase in total, inpatient, and outpatient daily censuses. These findings suggest that Massachusetts providers were more likely to expand outpatient treatment following the reform, thus on average treatment intensity may be lower post-reform.

Although one might expect that the coefficient estimates for outpatient and inpatient censuses to 'bracket' the total census estimate (total census is the sum of inpatient and outpatient censuses) we do not observe this pattern. However, composition changes in the samples of providers that provide inpatient and outpatient care lead to this pattern of results $(12 \%$ of providers offer both). In addition, $95 \%$ confidence intervals across the regressions overlap, and we cannot reject the hypotheses that the coefficients follow the above-noted bracketing pattern.

Examining dynamics of the relationship, we find that, relative to comparison states, admissions in Massachusetts providers increased gradually over the study period, with the largest gains occurring after 2009. This pattern of results is consistent with the hypothesis that providers may have adapted slowly to coverage and policy changes. Moreover, minimum credible coverage (MCC) requirements were not binding until 2009 (The Massachusetts Health Insurance Connector Authority, 2008), thus Massachusetts providers may have had less incentive to respond to the reform in the early period. We find the opposite pattern for inpatient daily censuses: effects are larger in the early period.

\section{IV.D Services, programs, and pharmacotherapies}


Findings for services, programs, and pharmacotherapies are reported in Table 4. On the one hand, following the reform Massachusetts SUD providers expanded the number of services and increased their use of pharmacotherapies relative to comparison states. The basic DD model suggests that Massachusetts providers increased their number of offered services by 0.471 (3.5\%) and their use of pharmacotherapies by 4.31 percentage points $(11.3 \%)$ following healthcare reform. However, following the reform, Massachusetts SUD providers reduced the number of programs by $0.759(24.1 \%)$ relative to providers in comparison states. Our dynamic models suggest that the reform effects increased over time.

\section{IV.E Payment}

Table 5 presents accepted forms of payments results. Our basic DD model suggests that, in response to healthcare reform, providers in Massachusetts altered the types of payments that they were willing to accept. The probability that a facility accepted private health insurance increased (1.84 percentage points, $2.7 \%$ ) while the probability that a facility accepted selfpayments decreased (1.48 percentage points, 1.7\%). Coefficient estimates suggest that providers decreased acceptance of Medicaid and provision of discounted care by 1.82 percentage points $(2.7 \%)$ and 1.19 percentage points (1.4\%) post-reform, but the estimates are imprecise.

Our results suggest that following the reform Massachusetts providers increased accepted of non-Medicaid public insurance relative to comparison states. We suspect that N-SSATS survey completers interpreted this category to include subsidized private health insurance plans that were part of the reform as non-Medicaid public insurance ('CommCare'). ${ }^{7}$ These plans served low income adults ineligible for Medicaid. Although subsidized plans were offered by the same insurers as plans in the private market, providers may have viewed subsidized plans as

\footnotetext{
${ }^{7}$ One of the options for non-Medicaid public insurance in the N-SSATS is: 'A state-financed health insurance plan other than Medicaid'.
} 
part of a new public program. Previous studies of insurance expansions have encountered such reporting errors (Kolstad and Kowalski, 2012, Lo Sasso and Buchmueller, 2004).

In our dynamic models we observe that the increase in the probability of accepting private and non-Medicaid public health insurance appears to 'ramp up' over time: coefficients are larger and more precisely estimated in late period. In contrast, findings for self-payment acceptance are driven primarily by the early period (2007-2009): the coefficient is negative and statistically significant in years 2007-2009 but becomes statistically indistinguishable from zero in the years 2010-2012. As in the basic model, although coefficient estimates suggest that providers reduced acceptance of Medicaid post-reform, they are imprecise. We find precise evidence that Massachusetts providers reduced discounted care provision in the late period.

\section{IV.F Ownership status}

We report results generated in Model 1 by ownership status in Tables 6A (admissions, daily censuses), 6B (services, programs, pharmacotherapies), and 6C (accepted forms of payments). In terms of admissions, daily censuses, services, programs, and pharmacotherapies our findings are broadly consistent with our predictions: the coefficients are generally larger in the for-profit sample. An exception is inpatient censuses: the coefficient is smaller among forprofits than non-profits (the former is imprecisely estimated). Findings are somewhat different across ownership status for payment variables. For-profit providers drive findings for private insurance, non-Medicaid public insurance, and discounted care. On the other hand, non-profits drive the findings for reductions in the probability of accepting self-payments. We find that Massachusetts non-profits are less likely to accept Medicaid following the reform.

\section{SECTION V. ROBUSTNESS CHECKS}

\section{V.A Alternative comparison group}


We re-estimate Model 1 using the Northeast states as a comparison group, since other states in the Northeast region may be more comparable to Massachusetts along some dimensions. ${ }^{8,9}$ Results are reported in Tables A1 (admissions, daily censuses), A2 (services, programs, pharmacotherapies), and A3 (accepted forms of payments). The findings are broadly comparable to our core model, although we are less likely to pass the parallel trends tests.

\section{V.B Market entrance}

A concern with our analysis is that our findings may be driven by changes in the composition of providers: providers may have entered the Massachusetts SUD treatment market following the reform. To explore this possibility, we use Model (1) to study how the number of providers (total, for-profit, and nonprofit) in a state changed after healthcare reform in Massachusetts relative to our comparison group. Findings are available on request. We observe no evidence that the composition of providers changed following the reform.

\section{V.C Government transfers}

A component of the reform was to reduce direct public transfers to safety-net healthcare providers. These transfers have historically played an important role in funding SUD treatment. We next examine to what extent the reform influenced the probability that a Massachusetts SUD facility reported receiving government transfer relative to providers in comparison states. Our findings, available on request, suggest that the reform reduced the probability that a Massachusetts facility reported receiving public transfers by roughly $3 \%$.

\section{SECTION VI. CONCLUSIONS}

\footnotetext{
${ }^{8}$ Northeast states include Connecticut, Delaware, Maine, Maryland, New Hampshire, New Jersey, New York, Pennsylvania, Rhode Island, and Vermont. Results are robust if we exclude Vermont, which implemented healthcare reform in our study period.

${ }^{9}$ In unreported analyses, we attempted to use New England states as a comparison group. However, parallel trends testing suggested that New England states did not form a suitable control group. We have also utilized all other states as a comparison (e.g., all other states) and results are comparable to those reported in this manuscript.
} 
We examined changes in the provision of specialty SUD treatment in Massachusetts after the implementation of a landmark 2006 law that achieved near universal health insurance coverage. Compared to providers in states not implementing reform, we found that admissions to treatment at specialty providers in Massachusetts increased by $17 \%$ post-reform. Daily censuses increased by $4.7 \%$ following the reform, and findings were stronger for outpatient than inpatient censuses. The increases generally accelerated over time. The significant increase contrasts with prior qualitative research suggesting that SUD treatment did not change in Massachusetts after 2006 (Capoccia et al., 2012). However, our findings are consistent with work on other insurance expansions and SUD treatment (Wen et al., 2013, Dave and Mukerjee, 2011, Maclean et al., 2015), and is also consistent with the finding that the Massachusetts reform lead to greater use of most healthcare services (Kolstad and Kowalski, 2012, Miller, 2012b).

We find other evidence that suggests providers strategically responded to new incentives under the Massachusetts reform. Compared to providers in comparison states, we observe that Massachusetts providers increased acceptance of private insurance, and reduced acceptance of self-paying and treatment provided for free or at a discount.

We find that Massachusetts providers may have increased acceptance of insurance forms that were not affected by the reform (non-Medicaid public insurance). We suspect, as has been identified in previous studies (Kolstad and Kowalski, 2012, Lo Sasso and Buchmueller, 2004), that misclassifications of insurance plans may drive this finding.

In terms of other provider responses, we find that providers in Massachusetts increased the number of services offered and their use of pharmacotherapies compared to providers in comparison states. In both cases, these changes in offerings may reflect some competitive 
pressures to attract insured clients who may value expanded treatment options (Pauly and Pagan, 2007). On the other hand, providers reduced their provision of programs for special populations.

One possibility for the reduction in programs for special populations is that new relationships with health insurers increased pressures for providers to only offer those services that can be covered using insurance billing codes (Kolstad and Kowalski, 2012). In addition, providers may have faced tradeoffs in meeting increased demand from newly insured individuals. When confronted with increasing treatment admissions or maintaining special programs (which by definition, serve only a subset of clients), providers may have opted to increase treatment slots overall and services that benefits a large share of clients. Lastly, the reform reduced financing previously made available to safety net providers through transfers. This reduction in government funding may have compromised the ability of providers to maintain service offerings when faced with increased demand for treatment slots.

Consistent with the idea that for-profit providers may be especially motivated to gain new revenues to maximize profits, we find that the response among for-profit providers was especially high in Massachusetts after the reform.

Our study has limitations. We lack an independent measure of demand for treatment. Second, we do not directly observe the profitability of accepting different patient populations. Third, our data source enables us to measure which types of insurance are accepted, but more nuanced issues such as intensity of provider participation in distinct insurance markets is not available with our data. Finally our reduced form approach does not allow us to completely separate demand and supply side effects.

Overall, our study confirms that SUD treatment providers in Massachusetts absorbed a higher volume of patients after the 2006 reform and changed the types of services they delivered. 
The implications of this reform for the health and wellbeing of these populations is an important topic for public policy and future research. 
TABLE 1. Summary statistics in the pre-reform period: N-SSATS 2004-2006

\begin{tabular}{|c|c|c|}
\hline Sample: & $\begin{array}{c}\text { Non-MA states, pre- } \\
\text { reform }\end{array}$ & $\begin{array}{c}\text { MA, } \\
\text { pre-reform }\end{array}$ \\
\hline & Mean/proportion & Mean/proportion \\
\hline \multicolumn{3}{|l|}{ Admissions/client volumes } \\
\hline Total annual admissions & 303.2 & 488.7 \\
\hline Total clients & 88.12 & 124.2 \\
\hline Inpatient clients (conditional on providing inpatient care) & 27.40 & 26.65 \\
\hline Outpatient clients (conditional on providing outpatient care) & 87.11 & 156.9 \\
\hline \multicolumn{3}{|l|}{ Service, programs, and pharmacotherapy } \\
\hline Number of services $(0-28) \dagger$ & 12.66 & 13.34 \\
\hline Number of programs $(0-12) \dagger \dagger$ & 2.911 & 3.152 \\
\hline Any pharmacotherapies $(0 / 1) \dagger \dagger \dagger$ & 0.252 & 0.383 \\
\hline \multicolumn{3}{|l|}{ Accepted forms of payment } \\
\hline Private & 0.720 & 0.671 \\
\hline Medicaid & 0.582 & 0.676 \\
\hline Other public & 0.570 & 0.622 \\
\hline Self-pay/other payment method & 0.924 & 0.876 \\
\hline Discounted care & 0.770 & 0.868 \\
\hline \multicolumn{3}{|l|}{ State-demographics* } \\
\hline Population & $9,135,910$ & $6,408,639$ \\
\hline Age & 36.53 & 37.29 \\
\hline Male & 0.490 & 0.486 \\
\hline Female & 0.510 & 0.514 \\
\hline Less than high school & 0.191 & 0.166 \\
\hline High school & 0.308 & 0.270 \\
\hline Some college & 0.259 & 0.216 \\
\hline College graduate & 0.242 & 0.349 \\
\hline White & 0.806 & 0.865 \\
\hline African American & 0.129 & 0.0677 \\
\hline Other race & 0.0649 & 0.0677 \\
\hline Hispanic & 0.110 & 0.0763 \\
\hline Family income & 79,600 & 101,840 \\
\hline Unemployment rate & 6.289 & 5.937 \\
\hline Observations & 32,428 & 951 \\
\hline \multicolumn{3}{|c|}{$\begin{array}{l}\text { Notes: Each row represents the mean for providers in the state groups in the years pre-reform. Non-MA states } \\
\text { include all non-MA states except California, Maine, Oregon, and Vermont. Results are weighted by the number of } \\
\text { providers in the state/year. } \\
\dagger \text { Services include comprehensive substance use disorder assessment at intake, comprehensive mental health } \\
\text { assessment at intake, blood alcohol testing, urine drug and alcohol testing, hepatitis B testing, hepatitis C testing, } \\
\text { HIV testing, STD testing, TB screen, discharge planning, aftercare counselling, case management, child care, social } \\
\text { services assistance, employment assistance, housing assistance, domestic violence education, HIV/AIDS education, } \\
\text { transportation assistance, acupuncture, residential beds for children, individual counselling, group counselling, } \\
\text { family counselling, outcome follow-up after discharge, and non-English treatment provided. } \\
\dagger † \text { Special programs include certified opioid treatment program, DUI/DWI, adolescents, dually-diagnosed, criminal } \\
\text { justice, HIV/AIDS, gays/lesbians, seniors, women, pregnant/postpartum women, men, and other. } \\
\dagger \dagger \dagger \text { Pharmacotherapies include Antabuse, Naltrexone, and Methadone. } \\
* \text { State-level characteristics are defined at the state level. }\end{array}$} \\
\hline
\end{tabular}


TABLE 2A. Validity of the differences-in-differences design for admissions and client volume outcomes: N-SSATS 2004-2006

\begin{tabular}{|c|c|c|c|c|}
\hline & $\begin{array}{c}\text { Log } \\
\text { admissions }\end{array}$ & $\begin{array}{c}\text { Log total } \\
\text { clients }\end{array}$ & $\begin{array}{c}\text { Log inpatient } \\
\text { clients }\end{array}$ & $\begin{array}{c}\text { Log outpatient } \\
\text { clients }\end{array}$ \\
\hline $\begin{array}{l}\text { Untransformed mean, MA pre- } \\
\text { reform }\end{array}$ & 488.7 & 124.2 & 26.65 & 156.9 \\
\hline \multicolumn{5}{|l|}{ Parallel trends test } \\
\hline Treat*time & $\begin{array}{l}-0.0050 \\
(0.0375)\end{array}$ & $\begin{array}{c}0.0477 \\
(0.0271)\end{array}$ & $\begin{array}{c}0.0540 \\
(0.0489)\end{array}$ & $\begin{array}{l}-0.0274 \\
(0.0607)\end{array}$ \\
\hline $\mathrm{N}$ & 30,217 & 30,720 & 10,360 & 27,691 \\
\hline
\end{tabular}

TABLE 2B. Validity of the differences-in-differences design for services, programs, and pharmacotherapies: N-SSATS 2004-2006

\begin{tabular}{lccc}
\hline \hline & $\begin{array}{c}\text { Number of } \\
\text { services }\end{array}$ & $\begin{array}{c}\text { Number of } \\
\text { programs }\end{array}$ & $\begin{array}{c}\text { Any } \\
\text { pharmacotherapies }\end{array}$ \\
\hline Mean/proportion, MA pre-reform & 13.34 & 3.152 & 0.383 \\
\hline Parallel trends test & & & 0.0019 \\
\hline Treat*time & 0.0842 & -0.1317 & $(0.0088)$ \\
\hline $\mathrm{N}$ & $(0.1003)$ & 11,911 & 32,436 \\
\hline
\end{tabular}

Notes: Unit of observation is a facility in a state/year. The comparison group includes all states except California, Maine, Oregon, and Vermont. All models control for population, demographics, unemployment rate, and state and year fixed effects. Standard errors clustered around the state and reported in parentheses.

$* * * ; * *=$ statistically different from zero at the $1 \% ; 5 \%$ level.

TABLE 2C. Validity of the differences-in-differences design for accepted forms of payments: N-SSATS 20042006

\begin{tabular}{lccccc}
\hline \hline & Private & Medicaid & $\begin{array}{c}\text { Other } \\
\text { public }\end{array}$ & $\begin{array}{c}\text { Self- } \\
\text { pay/other }\end{array}$ & $\begin{array}{c}\text { Discounted } \\
\text { care }\end{array}$ \\
\hline Proportion, MA pre-reform & 0.671 & 0.676 & 0.622 & 0.876 & 0.868 \\
\hline Parallel trends test & & & & & \\
\hline Treat*time & 0.0057 & -0.0217 & 0.0036 & $-0.0225^{* * *}$ & 0.0006 \\
& $(0.0088)$ & $(0.0122)$ & $(0.0098)$ & $(0.0058)$ & $(0.0068)$ \\
\hline $\mathrm{N}$ & 32,411 & 32,230 & 27,384 & 23,894 & 32,978 \\
\hline
\end{tabular}

Notes: Unit of observation is a facility in a state/year. The comparison group includes all states except California, Maine, Oregon, and Vermont. All models control for population, demographics, unemployment rate, and state and year fixed effects. Standard errors clustered around the state and reported in parentheses.

$* * * ; *=$ statistically different from zero at the $1 \% ; 5 \%$ level. 
TABLE 3. Effect of MA healthcare reform on admissions and client volumes: N-SSATS 2004-2012

\begin{tabular}{|c|c|c|c|c|}
\hline & $\begin{array}{c}\text { Log } \\
\text { admissions } \\
\end{array}$ & $\begin{array}{c}\text { Log total } \\
\text { clients }\end{array}$ & $\begin{array}{c}\text { Log inpatient } \\
\text { clients }\end{array}$ & $\begin{array}{c}\text { Log outpatient } \\
\text { clients }\end{array}$ \\
\hline $\begin{array}{l}\text { Untransformed mean, MA pre- } \\
\text { reform }\end{array}$ & 488.7 & 124.2 & 26.65 & 156.9 \\
\hline \multicolumn{5}{|l|}{ Model 1} \\
\hline $\mathrm{DD}$ & $\begin{array}{c}0.1705 * * * \\
(0.0241)\end{array}$ & $\begin{array}{c}0.0465 * * * \\
(0.0168)\end{array}$ & $\begin{array}{c}0.0794 * * * \\
(0.0262)\end{array}$ & $\begin{array}{c}0.1365 * * * \\
(0.0222)\end{array}$ \\
\hline $\mathrm{N}$ & 93,164 & 95,644 & 30,231 & 84,299 \\
\hline \multicolumn{5}{|l|}{ Model 2} \\
\hline DD early & $\begin{array}{c}0.0898 * * * \\
(0.0223)\end{array}$ & $\begin{array}{l}-0.0073 \\
(0.0187)\end{array}$ & $\begin{array}{c}0.0957 * * * \\
(0.0259)\end{array}$ & $\begin{array}{c}0.0379 \\
(0.0215)\end{array}$ \\
\hline DD late $\dagger$ & $\begin{array}{c}0.2525 * * * \\
(0.0313)\end{array}$ & $\begin{array}{c}0.0981 * * * \\
(0.0231)\end{array}$ & $\begin{array}{c}0.0621 \\
(0.0339) \\
\end{array}$ & $\begin{array}{c}0.2372 * * * \\
(0.0317)\end{array}$ \\
\hline $\mathrm{N}$ & 93,164 & 95,644 & 30,231 & 84,299 \\
\hline
\end{tabular}

Notes: Unit of observation is a facility in a state/year. The comparison group includes all states except California, Maine, Oregon, and Vermont. All models control for population, demographics, unemployment rate, and state and year fixed effects. Standard errors clustered around the state and reported in parentheses.

$\dagger$ DD early $=2007-2009$. DD late $=2010-2012$.

$* * * ; *=$ statistically different from zero at the $1 \% ; 5 \%$ level.

TABLE 4. Effect of MA healthcare reform on services, programs, and pharmacotherapies: N-SSATS 20042012

\begin{tabular}{|c|c|c|c|}
\hline & $\begin{array}{c}\text { Number of } \\
\text { services }\end{array}$ & $\begin{array}{c}\text { Number of } \\
\text { programs }\end{array}$ & $\begin{array}{c}\text { Any } \\
\text { pharmacotherapies }\end{array}$ \\
\hline Mean/proportion, MA pre-reform & 13.34 & 3.152 & 0.383 \\
\hline \multicolumn{4}{|l|}{ Model 1} \\
\hline $\mathrm{DD}$ & $\begin{array}{c}0.4707 * * * \\
(0.0654)\end{array}$ & $\begin{array}{c}-0.7589 * * * \\
(0.0514)\end{array}$ & $\begin{array}{c}0.0431 * * * \\
(0.0084)\end{array}$ \\
\hline $\mathrm{N}$ & 94,672 & 36,040 & 100,007 \\
\hline \multicolumn{4}{|l|}{ Model 2} \\
\hline DD early $\dagger$ & $\begin{array}{c}0.3997 * * * \\
(0.0613)\end{array}$ & $\begin{array}{c}-0.5661 * * * \\
(0.0527)\end{array}$ & $\begin{array}{c}0.0316 * * * \\
(0.0094)\end{array}$ \\
\hline DD late $\dagger$ & $\begin{array}{c}0.5408 * * * \\
(0.0786)\end{array}$ & $\begin{array}{c}-1.0374 * * * \\
(0.0641)\end{array}$ & $\begin{array}{c}0.0546 * * * \\
(0.0093)\end{array}$ \\
\hline $\mathrm{N}$ & 94,672 & 36,040 & 100,007 \\
\hline
\end{tabular}


TABLE 5. Effect of MA healthcare reform on accepted forms of payments: N-SSATS 2004-2012

\begin{tabular}{|c|c|c|c|c|c|}
\hline & Private & Medicaid & $\begin{array}{l}\text { Other } \\
\text { public }\end{array}$ & $\begin{array}{c}\text { Self- } \\
\text { pay/other }\end{array}$ & $\begin{array}{c}\text { Discounted } \\
\text { care }\end{array}$ \\
\hline Proportion, MA pre-reform & 0.671 & 0.676 & 0.622 & 0.876 & 0.868 \\
\hline \multicolumn{6}{|l|}{ Model 1} \\
\hline DD & $\begin{array}{r}0.0184 * * * \\
(0.0063)\end{array}$ & $\begin{array}{l}-0.0182 \\
(0.0126)\end{array}$ & $\begin{array}{c}0.0338 * * * \\
(0.0106)\end{array}$ & $\begin{array}{c}-0.0148 * * * \\
(0.0041)\end{array}$ & $\begin{array}{l}-0.0119 \\
(0.0062)\end{array}$ \\
\hline $\mathrm{N}$ & 99,332 & 99,063 & 86,716 & 85,357 & 100,716 \\
\hline \multicolumn{6}{|l|}{ Model 2} \\
\hline DD early† & $\begin{array}{c}0.0158 * * \\
(0.0064)\end{array}$ & $\begin{array}{l}-0.0112 \\
(0.0125)\end{array}$ & $\begin{array}{c}0.0260 * * \\
(0.0099)\end{array}$ & $\begin{array}{c}-0.0229 * * * \\
(0.0038)\end{array}$ & $\begin{array}{c}0.0111 \\
(0.0058)\end{array}$ \\
\hline DD late $\dagger$ & $\begin{array}{c}0.0210 * * * \\
(0.0073)\end{array}$ & $\begin{array}{l}-0.0252 \\
(0.0145)\end{array}$ & $\begin{array}{c}0.0418 * * * \\
(0.0124)\end{array}$ & $\begin{array}{l}-0.0082 \\
(0.0049)\end{array}$ & $\begin{array}{c}-0.0347 * * * \\
(0.0077)\end{array}$ \\
\hline $\mathrm{N}$ & 99,332 & 99,063 & 86,716 & 85,357 & 100,716 \\
\hline
\end{tabular}

Notes: Unit of observation is a facility in a state/year. The comparison group includes all states except California, Maine, Oregon, and Vermont. All models control for population, demographics, unemployment rate, and state and year fixed effects. Standard errors clustered around the state and reported in parentheses.

$\dagger$ DD early $=2007-2009$. DD late $=2010-2012$.

$* * * ; * *=$ statistically different from zero at the $1 \% ; 5 \%$ level.

TABLE 6A. Effect of MA healthcare reform on admissions and client volumes by ownership status: N-SSATS 2004-2012

\begin{tabular}{|c|c|c|c|c|}
\hline & $\begin{array}{c}\text { Log } \\
\text { admissions } \\
\end{array}$ & $\begin{array}{c}\begin{array}{c}\text { Log total } \\
\text { clients }\end{array} \\
\end{array}$ & $\begin{array}{c}\begin{array}{c}\text { Log inpatient } \\
\text { clients }\end{array} \\
\end{array}$ & $\begin{array}{c}\text { Log outpatient } \\
\text { clients }\end{array}$ \\
\hline \multicolumn{5}{|l|}{ Full sample } \\
\hline Mean, MA pre-reform & 488.7 & 124.2 & 26.65 & 156.9 \\
\hline $\mathrm{DD}$ & $\begin{array}{c}0.1705 * * * \\
(0.0241)\end{array}$ & $\begin{array}{c}0.0465 * * * \\
(0.0168)\end{array}$ & $\begin{array}{c}0.0794 * * * \\
(0.0262)\end{array}$ & $\begin{array}{c}0.1365 * * * \\
(0.0222)\end{array}$ \\
\hline $\mathrm{N}$ & 93,164 & 95,644 & 30,231 & 84,299 \\
\hline \multicolumn{5}{|l|}{ For-profit } \\
\hline Mean, MA pre-reform & 706.8 & 219.6 & 45 & 205.9 \\
\hline DD & $\begin{array}{c}0.5487 * * * \\
(0.0378)\end{array}$ & $\begin{array}{c}0.2086 * * * \\
(0.0342)\end{array}$ & $\begin{array}{c}0.0225 \\
(0.0633)\end{array}$ & $\begin{array}{c}0.1875 * * * \\
(0.0400)\end{array}$ \\
\hline $\mathrm{N}$ & 28,196 & 28,840 & 4,550 & 28,121 \\
\hline Non-profit & & & & \\
\hline Mean, MA pre-reform & 443.4 & 104.5 & 25.05 & 140.9 \\
\hline $\mathrm{DD}$ & $\begin{array}{c}0.0725 * * * \\
(0.0246)\end{array}$ & $\begin{array}{c}0.0059 \\
(0.0211) \\
\end{array}$ & $\begin{array}{c}0.0868 * * * \\
(0.0291)\end{array}$ & $\begin{array}{c}0.1102 * * * \\
(0.0238) \\
\end{array}$ \\
\hline $\mathrm{N}$ & 64,968 & 66,804 & 25,681 & 56,178 \\
\hline
\end{tabular}

Notes: Unit of observation is a facility in a state/year. The comparison group includes all states except California, Maine, Oregon, and Vermont. All models control for population, demographics, unemployment rate, and state and year fixed effects. Standard errors clustered around the state and reported in parentheses.

$* * * ; * *=$ statistically different from zero at the $1 \% ; 5 \%$ level. 
TABLE 6B. Effect of MA healthcare reform on services, programs, and pharmacotherapies by ownership status: N-SSATS 2004-2012

\begin{tabular}{|c|c|c|c|}
\hline & $\begin{array}{c}\text { Number of } \\
\text { services }\end{array}$ & $\begin{array}{c}\text { Number of } \\
\text { programs }\end{array}$ & $\begin{array}{c}\text { Any } \\
\text { pharmacotherapies }\end{array}$ \\
\hline \multicolumn{4}{|l|}{ Full sample } \\
\hline Mean, MA pre-reform & 13.34 & 3.152 & 0.383 \\
\hline DD & $\begin{array}{c}0.4707 * * * \\
(0.0654)\end{array}$ & $\begin{array}{c}-0.7589 * * * \\
(0.0514) \\
\end{array}$ & $\begin{array}{l}0.0431 * * * \\
(0.0084)\end{array}$ \\
\hline $\mathrm{N}$ & 94,672 & 36,040 & 100,007 \\
\hline \multicolumn{4}{|l|}{ For-profit } \\
\hline Mean, MA pre-reform & 13.66 & 3.355 & 0.624 \\
\hline DD & $\begin{array}{c}1.1777 * * * \\
(0.1106)\end{array}$ & $\begin{array}{c}-1.6832 * * * \\
(0.0918) \\
\end{array}$ & $\begin{array}{c}0.0860 * * * \\
(0.0131)\end{array}$ \\
\hline $\mathrm{N}$ & 28,392 & 11,443 & 29,879 \\
\hline \multicolumn{4}{|l|}{ Non-profit } \\
\hline Mean, MA pre-reform & 13.27 & 3.101 & 0.336 \\
\hline DD & $\begin{array}{c}0.2418 * * * \\
(0.0803)\end{array}$ & $\begin{array}{c}-0.4468 * * * \\
(0.0567)\end{array}$ & $\begin{array}{l}0.0210^{* *} \\
(0.0084)\end{array}$ \\
\hline $\mathrm{N}$ & 66,280 & 24,597 & 70,128 \\
\hline
\end{tabular}

TABLE 6C. Effect of MA healtheare reform on accepted forms of payment by ownership status: N-SSATS 2004-2012

\begin{tabular}{lccccc}
\hline \hline & Private & Medicaid & $\begin{array}{c}\text { Other } \\
\text { public }\end{array}$ & $\begin{array}{c}\text { Self- } \\
\text { pay/other }\end{array}$ & $\begin{array}{c}\text { Discounted } \\
\text { care }\end{array}$ \\
\hline Full sample & & & & & \\
\hline Mean, MA pre-reform & 0.671 & 0.676 & 0.622 & 0.876 & 0.868 \\
\hline $\mathrm{DD}$ & $0.0184^{* * *}$ & -0.0182 & $0.0338^{* * *}$ & $-0.0148^{* * *}$ & -0.0119 \\
& $(0.0063)$ & $(0.0126)$ & $(0.0106)$ & $(0.0041)$ & $(0.0062)$ \\
\hline $\mathrm{N}$ & 99,332 & 99,063 & 86,716 & 85,357 & 100,716 \\
\hline For-profit & & & & \\
\hline Mean, MA pre-reform & 0.844 & 0.836 & 0.695 & 0.991 & 0.613 \\
\hline $\mathrm{DD}$ & $0.0309^{* * *}$ & 0.0173 & $0.2008^{* * *}$ & -0.0061 & $-0.0644^{* * *}$ \\
& $(0.0108)$ & $(0.0151)$ & $(0.0154)$ & $(0.0031)$ & $(0.0099)$ \\
\hline $\mathrm{N}$ & 29,784 & 29,502 & 27,041 & 26,170 & 30,084 \\
\hline Non-profit & & & & & \\
\hline Mean, MA pre-reform & 0.634 & 0.642 & 0.607 & 0.854 & 0.920 \\
\hline $\mathrm{DD}$ & 0.0098 & $-0.0406^{* * *}$ & -0.0144 & $-0.0130^{* *}$ & -0.0040 \\
& $(0.0068)$ & $(0.0149)$ & $(0.0127)$ & $(0.0062)$ & $(0.0065)$ \\
\hline $\mathrm{N}$ & 69,548 & 69,561 & 59,675 & 59,187 & 70,632 \\
\hline
\end{tabular}

Notes: Unit of observation is a facility in a state/year. The comparison group includes all states except California, Maine, Oregon, and Vermont. All models control for population, demographics, unemployment rate, and state and year fixed effects. Standard errors clustered around the state and reported in parentheses.

$* * * ; * *=$ statistically different from zero at the $1 \% ; 5 \%$ level. 
TABLE A1. Effect of MA healthcare reform on admissions and client volumes using Northeast states as a comparison group: N-SSATS 2004-2012

\begin{tabular}{lcccc}
\hline \hline & $\begin{array}{c}\text { Log } \\
\text { admissions }\end{array}$ & $\begin{array}{c}\text { Log total } \\
\text { clients }\end{array}$ & $\begin{array}{c}\text { Log inpatient } \\
\text { clients }\end{array}$ & $\begin{array}{c}\text { Log outpatient } \\
\text { clients }\end{array}$ \\
\hline $\begin{array}{l}\text { Untransformed mean, MA pre- } \\
\text { reform }\end{array}$ & 488.7 & 124.2 & & \\
\hline $\mathrm{DD}$ & $0.1405^{* * *}$ & -0.0067 & 0.1351 & 156.9 \\
\hline $\mathrm{N}$ & $(0.0414)$ & $(0.0386)$ & $(0.0761)$ & $(0.0821$ \\
\hline Parallel trends test $\dagger$ & 22,833 & 23,374 & 8,067 & 18,308 \\
\hline Treat*time & & & & $0.6519^{* * *}$ \\
& -0.1241 & 0.0779 & $1.1146^{* * *}$ & $(0.1665)$ \\
\hline $\mathrm{N}$ & $(0.1204)$ & $(0.1098)$ & 2,759 & $6.1137)$ \\
\hline
\end{tabular}

Notes: Unit of observation is a facility in a state/year. The comparison group includes all Northeast states

(Connecticut, Delaware, Maine, Maryland, New Hampshire, New Jersey, New York, Pennsylvania, Rhode Island, and Vermont). All models control for population, demographics, unemployment rate, and state and year fixed effects. Standard errors clustered around the state and reported in parentheses.

$\dagger$ Parallel trends test based on pre-reform years (2004-2006).

$* * * ; * *=$ statistically different from zero at the $1 \% ; 5 \%$ level.

TABLE A2. Effect of MA healthcare reform on services, programs, and pharmacotherapies using Northeast states as a comparison group: N-SSATS 2004-2012

\begin{tabular}{lccc}
\hline \hline & $\begin{array}{c}\text { Number of } \\
\text { services }\end{array}$ & $\begin{array}{c}\text { Number of } \\
\text { programs }\end{array}$ & $\begin{array}{c}\text { Any } \\
\text { pharmacotherapies }\end{array}$ \\
\hline Mean/proportion, MA pre-reform & 13.34 & 3.152 & 0.383 \\
\hline $\mathrm{DD}$ & $0.4876^{* * *}$ & $-0.5631^{* * *}$ & 0.0247 \\
& $(0.1666)$ & $(0.2011)$ & $(0.0132)$ \\
\hline $\mathrm{N}$ & 22695 & 8433 & 23977 \\
\hline Parallel trends test $\dagger_{\dagger}$ & & & -0.0056 \\
& & 0.4496 & $(0.0190)$ \\
\hline $\mathrm{N}$ & $-2.5148^{* * *}$ & $(0.6404)$ & 7,863 \\
\hline
\end{tabular}

Notes: Unit of observation is a facility in a state/year. The comparison group includes all Northeast states

(Connecticut, Delaware, Maine, Maryland, New Hampshire, New Jersey, New York, Pennsylvania, Rhode Island, and Vermont). All models control for population, demographics, unemployment rate, and state and year fixed effects. Standard errors clustered around the state and reported in parentheses.

$\dagger \dagger$ Parallel trends test based on pre-reform years (2004-2006).

$* * * ; * *=$ statistically different from zero at the $1 \% ; 5 \%$ level. 
TABLE A3. Effect of MA healthcare reform on accepted forms of payments using Northeast states as a comparison group: N-SSATS 2004-2012

\begin{tabular}{|c|c|c|c|c|c|}
\hline & Private & Medicaid & Other public & $\begin{array}{c}\text { Self- } \\
\text { pay/other }\end{array}$ & Discounted \\
\hline Proportion, MA pre-reform & 0.6710 & 0.6757 & 0.6219 & 0.8764 & 0.8677 \\
\hline $\mathrm{DD}$ & $\begin{array}{c}0.0283 * * * \\
(0.0097) \\
\end{array}$ & $\begin{array}{c}-0.0066 \\
(0.0087) \\
\end{array}$ & $\begin{array}{c}0.0443 * * * \\
(0.0145) \\
\end{array}$ & $\begin{array}{c}-0.0262^{* *} \\
(0.0116) \\
\end{array}$ & $\begin{array}{c}0.0161 \\
(0.0140) \\
\end{array}$ \\
\hline $\mathrm{N}$ & 23769 & 23950 & 19783 & 20260 & 24195 \\
\hline \multicolumn{6}{|l|}{ Parallel trends test $\dagger$} \\
\hline Treat*time & $\begin{array}{c}0.1117 * * * \\
(0.0115)\end{array}$ & $\begin{array}{c}-0.0140 \\
(0.0623)\end{array}$ & $\begin{array}{c}0.1142 * * * \\
(0.0222)\end{array}$ & $\begin{array}{c}-0.0050 \\
(0.0648)\end{array}$ & $\begin{array}{c}0.0387 \\
(0.0532) \\
\end{array}$ \\
\hline $\mathrm{N}$ & 7,862 & 7,951 & 6,406 & 5,698 & 8,056 \\
\hline \multicolumn{6}{|c|}{$\begin{array}{l}\text { Notes: Unit of observation is a facility in a state/year. The comparison group includes all Northeast states } \\
\text { (Connecticut, Delaware, Maine, Maryland, New Hampshire, New Jersey, New York, Pennsylvania, Rhode Island, } \\
\text { and Vermont). All models control for population, demographics, unemployment rate, and state and year fixed } \\
\text { effects. Standard errors clustered around the state and reported in parentheses. } \\
\dagger \text { Parallel trends test based on pre-reform years }(2004-2006) \text {. } \\
* * * ; * *=\text { statistically different from zero at the } 1 \% ; 5 \% \text { level. }\end{array}$} \\
\hline
\end{tabular}


FIGURE A1. Admissions and client volumes N-SSATS 2004-2012: MA vs. comparison group

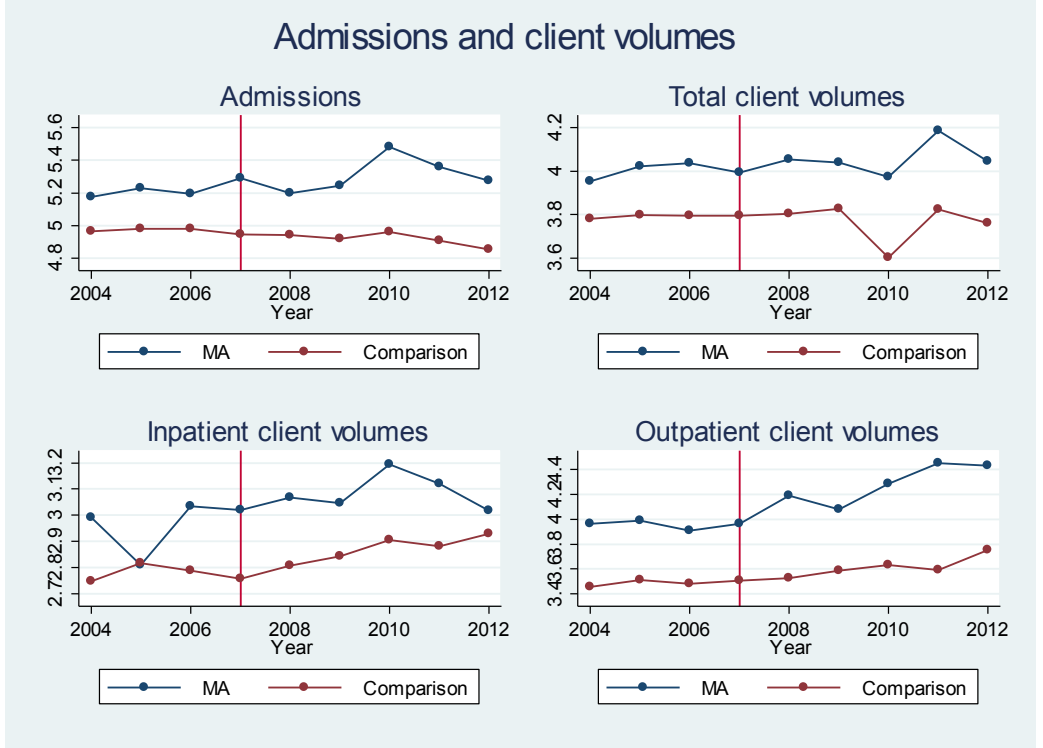

Notes: Data source is the 2004-2012 N-SSATS. Variables are in log form. The comparison group includes all states except California, Maine, Oregon, and Vermont. Vertical line indicates the year in which healthcare reform effective in N-SSATS (2007). Data are weighted by the number of providers in a state.

FIGURE A2. Services, programs, and pharmacotherapies N-SSATS 2004-2012: MA vs. comparison group

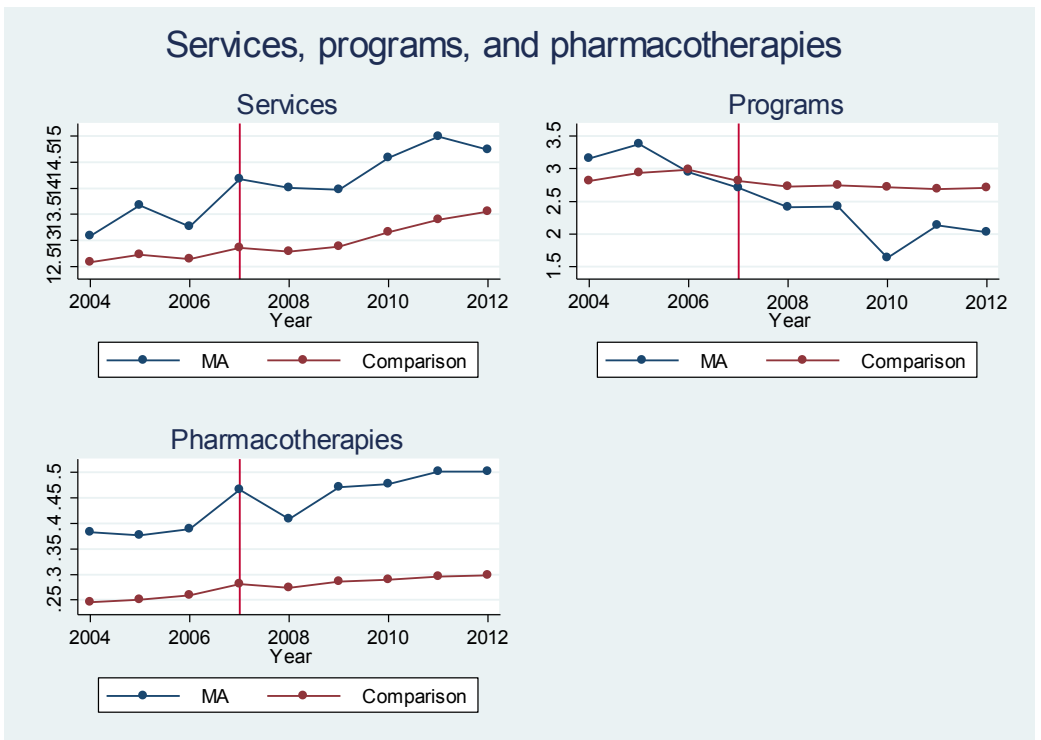

Notes: Data source is the 2004-2012 N-SSATS. The comparison group includes all states except California, Maine, Oregon, and Vermont. Vertical line indicates the year in which healthcare reform effective in N-SSATS (2007). Data are weighted by the number of providers in a state. 
FIGURE A3. Accepted forms of payment N-SSATS 2004-2012: MA vs. comparison group

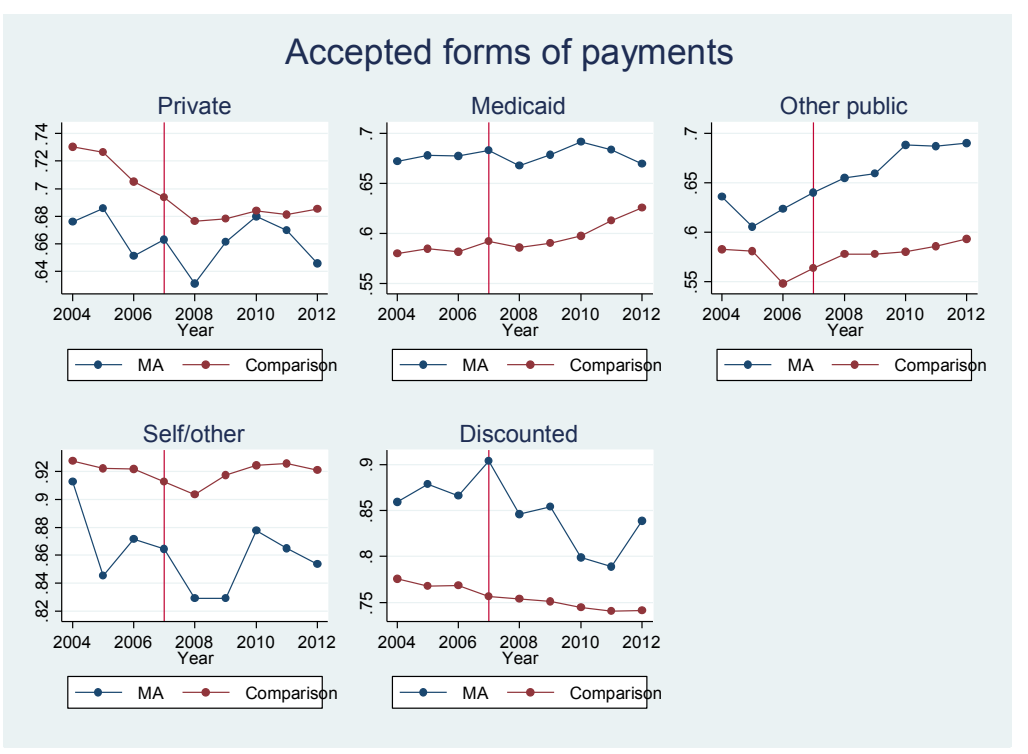

Notes: Data source is the 2004-2012 N-SSATS. The comparison group includes all states except California, Maine, Oregon, and Vermont. Vertical line indicates the year in which healthcare reform effective in N-SSATS (2007). Data are weighted by the number of providers in a state. 


\section{References}

ADAMS, S., BLACKBURN, M. L. \& COTTI, C. D. 2012. Minimum Wages and AlcoholRelated Traffic Fatalities among Teens. Review of Economics and Statistics, 94, 828-840.

ANDERSON, A. 2014. The Impact of the Affordable Care Act on the Health Care Workforce. In: FOUNDATION, T. H. (ed.) The Backgrouder. Washington, DC: The Heritage Foundation.

ANDREWS, C. M., SHIN, H. C., MARSH, J. C. \& CAO, D. 2013. Client and program characteristics associated with wait time to substance abuse treatment entry. Am J Drug Alcohol Abuse, 39, 61-8.

BACHHUBER, M. A., SOUTHERN, W. N. \& CUNNINGHAM, C. O. 2014. Profiting and providing less care: comprehensive services at for-profit, nonprofit, and public opioid treatment programs in the United States. Med Care, 52, 428-34.

BALSA, A. I., FRENCH, M. T., MACLEAN, J. C. \& NORTON, E. C. 2009. From Pubs to Scrubs: Alcohol Misuse and Health Care Use. Health Services Research, 44, 1480-1503.

BUCK, J. A. 2011. The looming expansion and transformation of public substance abuse treatment under the Affordable Care Act. Health Aff (Millwood), 30, 1402-10.

BUSCH, S. H., MEARA, E., HUSKAMP, H. A. \& BARRY, C. L. 2013. Characteristics of Adults With Substance Use Disorders Expected to Be Eligible for Medicaid Under the ACA. Psychiatric services (Washington, D.C.), 64, 520-526.

CAPOCCIA, V. A., GRAZIER, K. L., TOAL, C., FORD, J. H. \& GUSTAFSON, D. H. 2012. Massachusetts's Experience Suggests Coverage Alone Is Insufficient To Increase Addiction Disorders Treatment. Health Affairs, 31, 1000-1008.

CARPENTER, C. 2007. Heavy alcohol use and crime: Evidence from underage drunk-driving laws. Journal of Law \& Economics, 50, 539-557.

CARPENTER, C. \& DOBKIN, C. 2009. The Effect of Alcohol Consumption on Mortality: Regression Discontinuity Evidence from the Minimum Drinking Age. American Economic Journal-Applied Economics, 1, 164-182.

CARR, C. J. A., XU, J. M., REDKO, C., LANE, D. T., RAPP, R. C., GORIS, J. \& CARLSON, R. G. 2008. Individual and system influences on waiting time for substance abuse treatment. Journal of Substance Abuse Treatment, 34, 192-201.

CAWLEY, J., MORIYA, A. S. \& SIMON, K. 2013. The Impact of the Macroeconomy on Health Insurance Coverage: Evidence from the Great Recession. Health Econ, n/a-n/a.

CONGRESSIONAL BUDGET OFFICE 2013. CBO's February 2013 Estimate of the Effects of the Affordable Care Act on Health Insurance Coverage. Washington, DC: Congressional Budget Office.

COURTEMANCHE, C. J. \& ZAPATA, D. 2014. Does Universal Coverage Improve Health? The Massachusetts Experience. Journal of Policy Analysis and Management, 33, 36-69.

DAVALOS, M. E., FANG, H. \& FRENCH, M. T. 2012. Easing the pain of an economic downturn: macroeconomic conditions and excessive alcohol consumption. Health Econ, $21,1318-35$.

DAVE, D. \& MUKERJEE, S. 2011. Mental Health Parity Legislation, Cost-Sharing and Substance-Abuse Treatment Admissions. Health Economics, 20, 161-183.

GRUBER, J. 2008. Massachusetts Health Care Reform: The View From One Year Out. Risk Management and Insurance Review, 11, 51-63. 
GRUBER, J. 2011. Massachusetts points the way to successful health care reform. Journal of Policy Analysis and Management, 30, 184-192.

HORWITZ, J. R. 2005. Making Profits And Providing Care: Comparing Nonprofit, For-Profit, And Government Hospitals. Health Affairs, 24, 790-801.

INSTITUTE OF MEDICINE 2000. America's Health Care Safety Net: Intact but Endangered. Washington, DC: Institute of Medicine.

JAYAKODY, R., DANZIGER, S. \& POLLACK, H. 2000. Welfare Reform, Substance Use, and Mental Health. Journal of Health Politics, Policy and Law, 25, 623-652.

KAISER FAMILY FOUNDATION. 2015. Medicaid Benefits: Rehabilitation Services - Mental Health and Substance Abuse [Online]. Available: http://kff.org/medicaid/stateindicator/rehabilitation-services-mental-health-and-substance-abuse/ [Accessed May 23 2015].

KATZ, M. H. 2010. Future of the safety net under health reform. JAMA, 304, 679-680.

KOLSTAD, J. T. \& KOWALSKI, A. E. 2012. The impact of health care reform on hospital and preventive care: Evidence from Massachusetts. Journal of Public Economics, 96, 909929.

KU, L., JONES, E., SHIN, P., BYRNE, F. \& LONG, S. K. 2011. Safety-net providers after health care reform: Lessons from massachusetts. Archives of Internal Medicine, 171, 1379-1384.

LAKDAWALLA, D. \& PHILIPSON, T. 2006. The nonprofit sector and industry performance. Journal of Public Economics, 90, 1681-1698.

LEVIT, K. R., STRANGES, E., COFFEY, R. M., KASSED, C., MARK, T. L., BUCK, J. A. \& VANDIVORT-WARREN, R. 2013. Current and future funding sources for specialty mental health and substance abuse treatment providers. Psychiatr Serv, 64, 512-9.

LO SASSO, A. T. \& BUCHMUELLER, T. C. 2004. The effect of the state children's health insurance program on health insurance coverage. Journal of Health Economics, 23, 10591082.

LONG, S. K. 2008. On The Road To Universal Coverage: Impacts Of Reform In Massachusetts At One Year. Health Affairs, 27, w270-w284.

LONG, S. K. \& MASI, P. B. 2009. Access and affordability: an update on health reform in Massachusetts, fall 2008. Health Aff (Millwood), 28, w578-87.

LONG, S. K., STOCKLEY, K. \& YEMANE, A. 2009. Another Look at the Impacts of Health Reform in Massachusetts: Evidence Using New Data and a Stronger Model. American Economic Review, 99, 508-11.

LU, M. \& MCGUIRE, T. G. 2002. The Productivity of Outpatient Treatment for Substance Abuse. The Journal of Human Resources, 37, 309-335.

MACLEAN, J. C., POPOVICI, I. \& STERN, E. 2015. Health Insurance Expansions and Provider Behavior: Evidence from Substance Use Disorder Providers. Temple University.

MCCORMICK, D., SAYAH, A., LOKKO, H., WOOLHANDLER, S. \& NARDIN, R. 2012. Access to care after Massachusetts' health care reform: a safety net hospital patient survey. J Gen Intern Med, 27, 1548-54.

MCLELLAN, A. T., CARISE, D. \& KLEBER, H. D. 2003. Can the national addiction treatment infrastructure support the public's demand for quality care? Journal of Substance Abuse Treatment, 25, 117-21. 
MILLER, S. 2012a. The effect of insurance on emergency room visits: An analysis of the 2006 Massachusetts health reform. Journal of Public Economics, 96, 893-908.

MILLER, S. 2012b. The Effect of the Massachusetts Reform on Health Care Utilization. INQUIRY: The Journal of Health Care Organization, Provision, and Financing, 49, $317-$ 326.

MOHAN, A., GRANT, J., BATALDEN, M. \& MCCORMICK, D. 2013. The Health of Safety Net Hospitals following Massachusetts Health Care Reform: Changes in Volume, Revenue, Costs, and Operating Margins from 2006 to 2009. International Journal of Health Services, 43, 321-335.

NARDIN, R., SAYAH, A., LOKKO, H., WOOLHANDLER, S. \& MCCORMICK, D. 2012. Reasons Why Patients Remain Uninsured after Massachusetts' Health Care Reform: A Survey of Patients at a Safety-Net Hospital. Journal of General Internal Medicine, 27, 250-256.

NATIONAL INSTITUTE ON DRUG ABUSE 2012. Principles of Drug Addition Treatment: A Research-based Guide. In: ABUSE, N. I. O. D. (ed.) 3 ed. Bethesda, MD: United States Department of Health and Human Services.

OLMSTEAD, T. A. \& SINDELAR, J. L. 2005. Does the impact of managed care on substance abuse treatment services vary by provider profit status? Health Services Research, 40, 1862-1882.

PAULY, M. V. \& PAGAN, J. A. 2007. Spillovers and vulnerability: The case of community uninsurance. Health Affairs, 26, 1304-1314.

REDLENER, I. \& GRANT, R. 2009. America's Safety Net and Health Care Reform - What Lies Ahead? New England Journal of Medicine, 361, 2201-2204.

SALONER, B. \& COOK, B. 2014. An ACA Provision Increased Treatment For Young Adults With Possible Mental Illnesses Relative To Comparison Group. Health Aff (Millwood), 33, 1425-34.

SHIELDS, A. E., SHIN, P., LEU, M. G., LEVY, D. E., BETANCOURT, R. M., HAWKINS, D. \& PROSER, M. 2007. Adoption Of Health Information Technology In Community Health Centers: Results Of A National Survey. Health Affairs, 26, 1373-1383.

SILVERMAN, E. \& SKINNER, J. 2004. Medicare upcoding and hospital ownership. Journal of Health Economics, 23, 369-389.

SLOAN, F. A., PICONE, G. A., TAYLOR JR, D. H. \& CHOU, S.-Y. 2001. Hospital ownership and cost and quality of care: is there a dime's worth of difference? Journal of Health Economics, 20, 1-21.

SOMMERS, B. D., LONG, S. K. \& BAICKER, K. 2015. Changes in mortality after massachusetts health care reform. Ann Intern Med, 162, 668-9.

STEIN, B. D., GORDON, A. J., DICK, A. W., BURNS, R. M., PACULA, R. L., FARMER, C. M., LESLIE, D. L. \& SORBERO, M. 2015. Supply of buprenorphine waivered physicians: The influence of state policies. Journal of Substance Abuse Treatment, 48, 104-111.

STEWART, D., GOSSOP, M. \& MARSDEN, J. 2002. Reductions in non-fatal overdose after drug misuse treatment: results from the National Treatment Outcome Research Study (NTORS). Journal of Substance Abuse Treatment, 22, 1-9.

SWENSEN, I. D. 2015. Substance-abuse treatment and mortality. Journal of Public Economics, $122,13-30$. 
TANG, S. F., YUDKOWSKY, B. K. \& DAVIS, J. C. 2003. Medicaid participation by private and safety net pediatricians, 1993 and 2000. Pediatrics, 112, 368-72.

THE MASSACHUSETTS HEALTH INSURANCE CONNECTOR AUTHORITY 2008. Report to the Massachusetts Legislature: Implementation of the Health Care Reform Law, Chapter 58, 2006-2008.

WEN, H., CUMMINGS, J. R., HOCKENBERRY, J. M., GAYDOS, L. M. \& DRUSS, B. G. 2013. State parity laws and access to treatment for substance use disorder in the united states: Implications for federal parity legislation. JAMA Psychiatry, 70, 1355-1362. 